\title{
Outdoor thermal comfort: the effects of urban landscape morphology on microclimatic conditions in a hot-humid city
}

\author{
S. K. Syed Othman Thani, N. H. Nik Mohamad \\ \& S. Norjihan Jamaludin \\ Faculty of Architecture, Planning and Surveying, \\ Universiti Teknologi MARA, Malaysia
}

\begin{abstract}
As regions that are close to the equator, urban landscapes of hot-humid tropics are often exposed to the high intensity of solar radiation. The increasing heat gain and reduced evaporation in tropical outdoor environment has resulted to the overheating of urban areas, thus contributing to the outdoor thermal discomfort. The aim of this study is to investigate the effect of morphological aspect on the microclimatic condition in location of various urban landscapes morphology in Putrajaya. Field measurements were conducted to obtain temperature, relative humidity and wind speed variations at various urban spaces. Results showed that microclimatic condition exhibited variations in different urban landscapes. The findings indicated that the urban landscape morphology strongly influenced microclimatic conditions in the study area. The outcome of the study is hoped to contribute towards better understanding on the interrelationship of urban landscape variables and its implication to the outdoor environment in hot-humid climate. The applied understanding on the influence of landscape and urban morphology could provide detailed information to planners and architects especially in determining the design aspects that helps to promote outdoor thermal comfort in hot-humid environment.

Keywords: hot-humid city, microclimatic condition, outdoor thermal comfort, landscape design approaches.
\end{abstract}




\section{Introduction}

Nowadays, almost all cities are sources of heat due to the complexity of urbandesigned structures with higher thermal admittance and anthropogenic heat. The conversion of the natural landscape to a built, largely impermeable landscape and the introduction of new surface materials such as asphalt, concrete, tiles and others has dramatically modified the radiation, thermal, moisture, roughness and emissions properties of the surface and the atmosphere above [1]. These modifications of land cover and urban surface cause the local air and surface temperatures to rise several degrees higher than the surrounding rural areas.

Urban landscapes that comprises of various features give impact to the urban climate. The composition of urban fabrics, natural and man-made surfaces, urban geometry, street layout, architectural complexity, thermal materials and human activities characterised the urban landscape morphology, and give influences to its local climate [2]. As a consequence, the composition of urban landscape has affected the microclimatic condition of urban atmosphere [3].

This research aims to investigate the influence of various urban landscapes morphology on microclimatic fluctuation in different areas of Putrajaya. In addition, this research also aims to explore the potential of utilising urban landscape approaches, strategies and elements that effectively provide the cooling effects towards promoting outdoor thermal comfort in hot-humid environment. The findings would assist in identifying the appropriate urban landscape features that contribute to the moderation of microclimate.

\section{Literature review}

\subsection{Relationship of landscape morphology on urban thermal environment}

There is common contention among researchers that there is a close relationship between various urban factors including urban design, lack of vegetation cover, anthropogenic heat generation and thermal characteristics of urban materials and surfaces, that cause the alteration of urban climate [1, 4, 5]. Emmanuel and Johansson [4] observed that urban morphology and landscape characteristics has a major influence as contributing factors to the establishment of urban heating. Inappropriate landscape planning and urban design by replacing natural vegetation to impermeable surfaces is recognised to significantly contribute to the deterioration of urban environment. According to Oke [6], the modified urban climate has resulted in the occurrence of Urban Heat Island phenomenon where its affects the thermal comfort of urban environment and their inhabitants. Reducing and removing vegetation for placement of buildings blocks modify the temperature conditions near the ground level; where less vegetation means a higher urban temperature.

The architectural details of the urban structure such as the use of dark coloured roofs and walls tend to increase absorption of solar radiation; building and the used of construction materials that are not climate-friendly contribute to the excessive heat and dependencies towards air conditioning to cooling for 
comfort. All of these factors eventually led to the rise of energy consumption thus triggering more and more heat to the urban environment [1, 6].

The good understanding on the influence of landscape and urban morphology with microclimatic variation would provide useful information in identifying the significant landscape design elements that could contribute to promote a comfortable thermal environment, especially in hot-humid climate [2, 7].

\subsection{Climate-responsive design}

\subsubsection{Approach and elements of landscape design to promote thermal comfort}

\section{(a) Bioclimatic components}

Discussion on urban planning and design for outdoor environments normally entails the bioclimatic and microclimatic components that should be put into accounts at the initial phase of design. Yeang [8] and Olygay [9] define that the term "bioclimatic" refers to the relations of climate and life, particularly the effects of climate on living things. Thus, the bioclimatic aspect in designing an urban landscape is necessary due to its strong relationship with climate, nature and living environment. Bioclimatic approach in urban landscape design is the intensive and extensive use of urban greenery, body of water elements and landscape design structures in response with climatic variability [10-12].

Sun et al. [13] observed the cooling effects of wetlands as Urban Cool Island (UCI) in Beijing, China. They found out that, on average, wetlands are cooler than their surrounding landscapes but its characteristics can impact the cooling effect in urban regions. It was also observed that the flowing water bodies such as river is recorded a lower temperature (the difference of 1.5 to $3.15^{\circ} \mathrm{C}$ ) than the stagnant water surface such as reservoir and lakes [14]. These indicated that urban landscape design that incorporates an essential amount of bioclimatic elements is believed to relieve urban heating. Furthermore, the use of natural resources like vegetation and water bodies contributes to the urban thermal improvement from cooling-island effect, promote more ecologically sound and pleasant living environment through climate adaptation.

\section{(b) Utilisation of natural vegetation}

The abundance and morphology of natural vegetation in tropical climate can be utilised as a suitable design elements to improve the microclimate. The selection of vegetation should consider native and ecologically restorative rather than ornamental types, and choice of species should reflect the bioclimatic requirements. In addition, the uses of native vegetation will facilitate the adaptation to local climate. Previous researches have indicated that natural tropical vegetation is capable to provide thermal benefit. Few tropical tree species like Messua ferrea (Ironwood tree) and Hurra crepitans (Indonesian Umbrella Tree) can lower ground surface temperature by reducing amount of terrestrial radiation by $93 \%$ and $79 \%$ underneath the canopy. In addition, the 
layered structure of tropical rainforest can be manipulated as one of a design solution. Tropical landscape designers can apply the concept of 'forest mimicry' or emulate the natural forest by mimicking the multi-layered plant composition into their design in hot-humid outdoor spaces. This could help in providing shades and thermal buffer, and increase the humidity to promote outdoor thermal comfort. Table 1 provides information on vegetal characteristics of some native species of tropical trees that can be utilised as passive cooling effects in moderating the microclimate.

Table 1: Vegetal characteristics of some tropical species that provide thermal benefits.

\begin{tabular}{|c|c|c|}
\hline $\begin{array}{l}\text { Tropical native } \\
\text { species }\end{array}$ & Vegetal characteristics & $\begin{array}{l}\text { Potential utilisation in } \\
\text { landscape design }\end{array}$ \\
\hline \multirow[t]{6}{*}{ Messua ferrea } & $\begin{array}{l}\text { Dense tree canopy, branches } \\
\text { and twig }\end{array}$ & $\begin{array}{l}\text { Solar radiation } \\
\text { modification and full } \\
\text { shaded effect }\end{array}$ \\
\hline & 6.1 Leaf Area Index (LAI) & $\begin{array}{l}\text { Effective microclimate } \\
\text { moderator }\end{array}$ \\
\hline & $5 \%$ transmissivity value & $\begin{array}{l}\text { Thermal buffer } \\
\text { planting }\end{array}$ \\
\hline & $35 \%$ shade area & \\
\hline & $\begin{array}{l}7 \% \text { average of radiant heat } \\
\text { transfer under canopy }\end{array}$ & \\
\hline & $93 \%$ of solar attenuation & \\
\hline \multirow[t]{5}{*}{ Hura crepitans } & $\begin{array}{l}\text { Modest tree canopy cover, } \\
\text { branches and twig }\end{array}$ & $\begin{array}{l}\text { Effective in providing } \\
\text { shades }\end{array}$ \\
\hline & 1.5 Leaf Area Index (LAI) & Street planting \\
\hline & $79 \%$ average heat filtration & $\begin{array}{l}\text { Planting in parking and } \\
\text { open spaces }\end{array}$ \\
\hline & $22 \%$ transmissivity value & \\
\hline & $52 \%$ shade area & \\
\hline \multirow[t]{2}{*}{$\begin{array}{l}\text { Maniltoa } \\
\text { schefferi }\end{array}$} & $\begin{array}{l}\text { Dense canopy (round } \\
\text { spreading types), massive } \\
\text { leaves and tree branches }\end{array}$ & $\begin{array}{l}\text { Lowering air } \\
\text { temperature and } \\
\text { increasing the humidity }\end{array}$ \\
\hline & $\begin{array}{l}\text { Reduce the temperature by } \\
4.8-7.4^{\circ} \mathrm{C} \text { and increase the } \\
\text { humidity up to } 3.9 \% \text { under } \\
\text { the tree canopy }\end{array}$ & $\begin{array}{l}\text { Planting in open } \\
\text { space/park }\end{array}$ \\
\hline
\end{tabular}

(Source: adapted and modified from Shahidan et al. [15] and Hidayat [16]). 


\section{$3 \quad$ Materials and method}

\subsection{Study area}

The study was carried out within the city of Putrajaya (Lat. $2^{\circ} 55^{\prime} 34.90 " \mathrm{~N}$, Long. $101^{\circ} 41^{\prime} 47.20^{\prime \prime E}$ ), the new federal Government Administrative Centre of Malaysia. As the contemporary township development, Putrajaya's land uses and land covers vary from administrative centres, neighbourhood and residential precincts, commercial centres and large urban parks and water bodies [17]. These elements give the unique features of its urban landscape environment. Therefore, it is suitable to investigate the influence of urban landscape morphology to the microclimatic condition. Figure 1 shows the macro view and boundary of Putrajaya city through satellite imagery (SPOT-5).

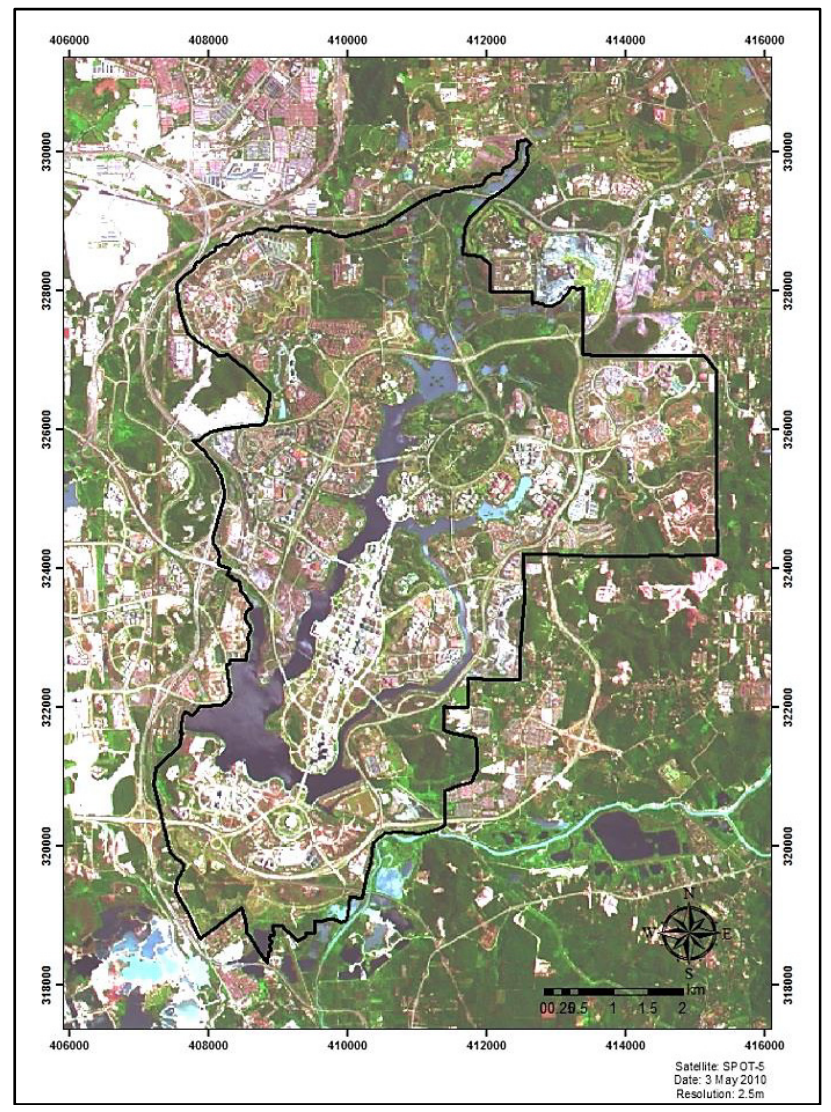

Figure 1: The satellite imagery (SPOT-5) showing the macro view of the study area. 


\subsection{Sampling locations and measurement procedure}

Fifteen point sources were selected for measurements within Putrajaya city (Figure 2). The samples are disproportionally taken across all types of land use and land cover, and varied by dissimilarities of urban characteristics such as at different urban geometry and structures, surfaces, activities and others which are assumed to be representing the characteristics of the city.

The climatic parameters used for field measurement are air temperature $\left({ }^{\circ} \mathrm{C}\right)$, relative humidity (\%) and wind speed $\left(\mathrm{ms}^{-1}\right)$. The field measurements were taken from January to March 2012 for two to three times a week including weekdays and weekend (altogether 35 days of observation). The field measurements were taken on calm and clear weather excluding rainy days. The measurements were conducted around 1100 to 1400 in the mid-afternoon.

The measurement at each selected sampling stations were obtained by using a handheld thermo-anemometer model Lutron LM-8000. The instrument had temperature, humidity and wind speed resolution of $0.1^{\circ} \mathrm{C}, 0.1 \%$ and $0.1 \mathrm{~ms}^{-1}$ respectively. Before beginning the field work, the instruments were calibrated to ensure it is in good condition and does not affect the measurement taken.

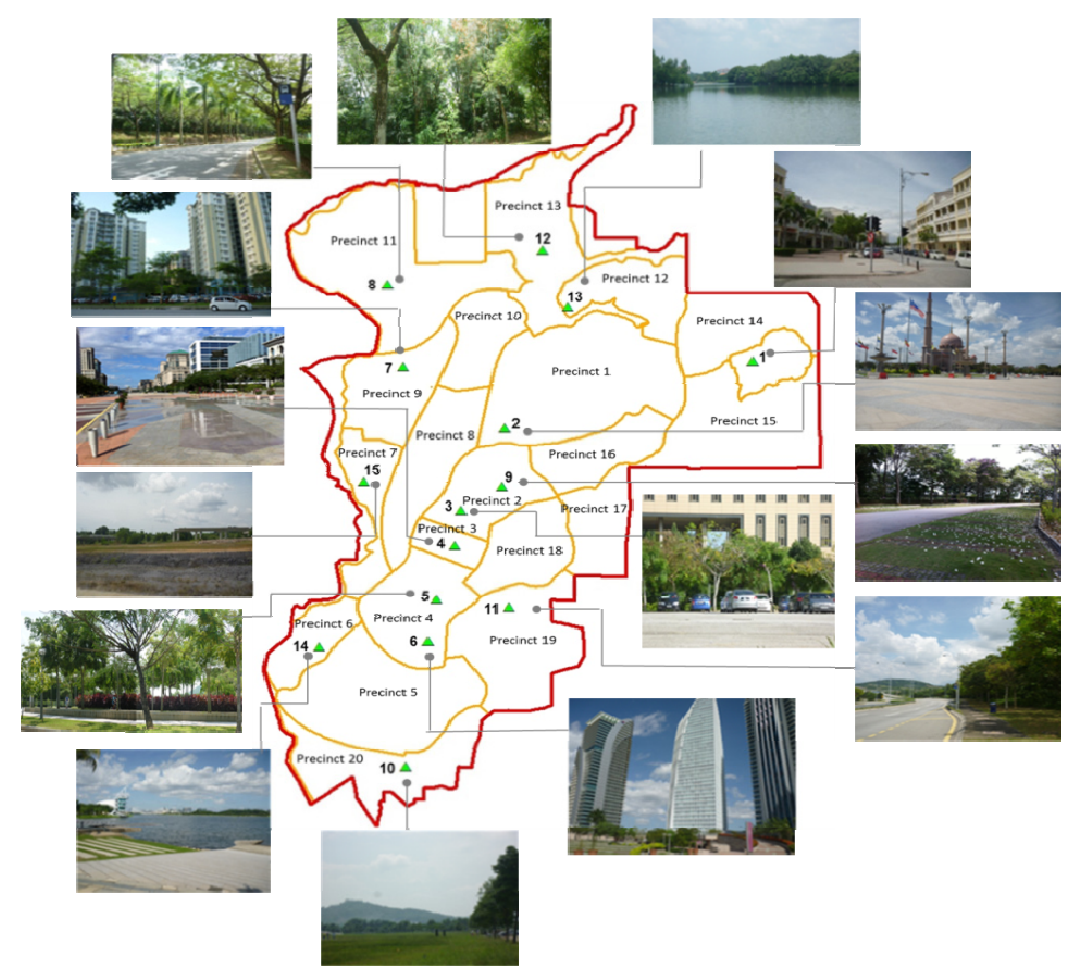

Figure 2: $\quad$ The measurement points in the study area. 


\section{Summary of results and discussion}

\subsection{Variation of climatic parameter}

The collected field data were averaged to represent mean temperature, relative humidity and wind speed distribution for that particular period. Generally, the results demonstrated significant variations between variables (Figure 3).

As plotted in the graph, it was observed that the points located within the urban centred (Point 1, 3, 4, 6 and 7) recorded high temperature (average of 36 to $39^{\circ} \mathrm{C}$ ) and low humidity (42.4 to $\left.49.6 \%\right)$. Nevertheless, the green areas and area nearby water body (Point 9, 12, and 13) were registered low temperature (average of 33 to $34^{\circ} \mathrm{C}$ ) and high humidity (between 51.4 to $55.9 \%$ ).

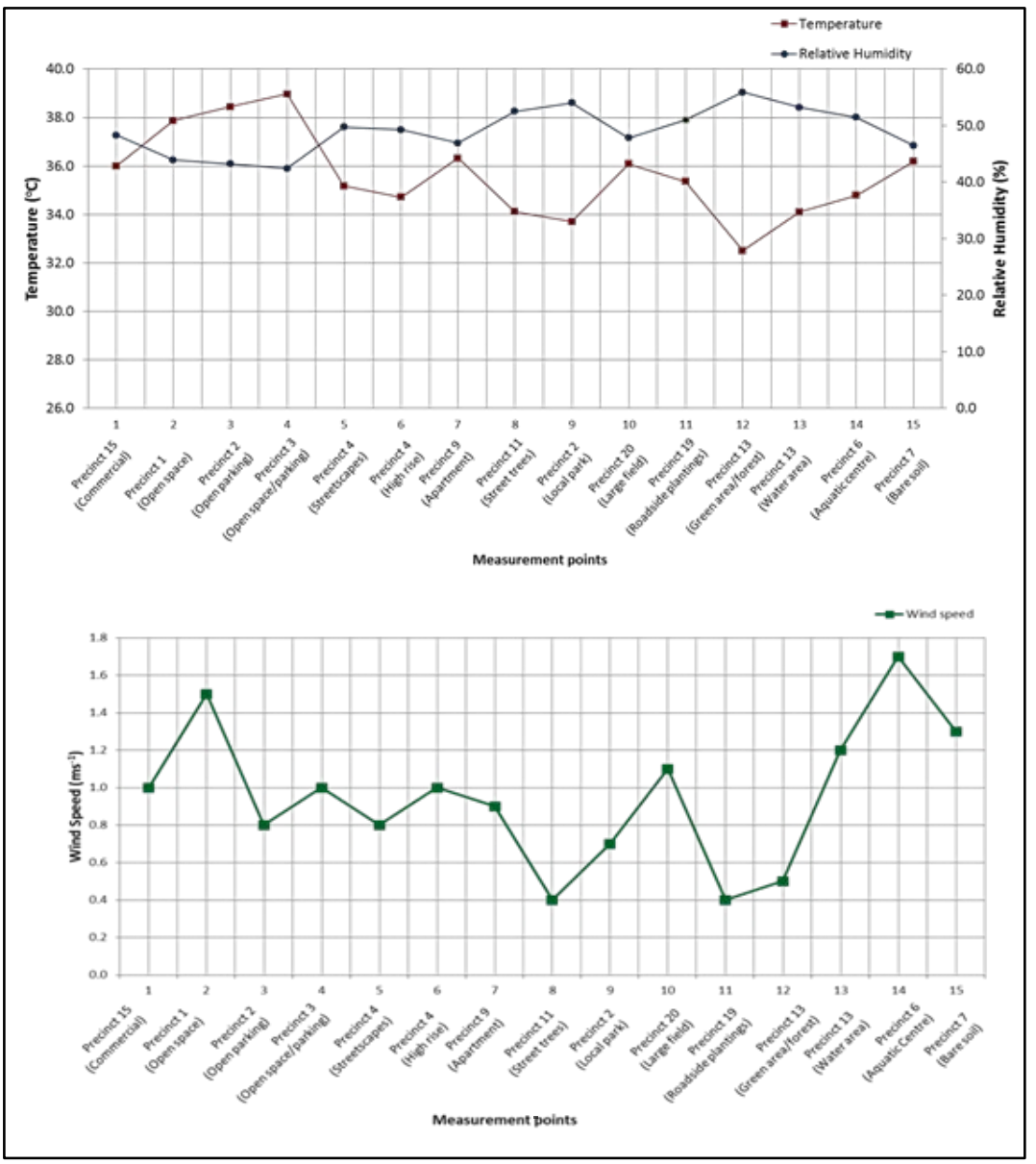

Figure 3: Variation of average temperature, relative humidity and wind speed. 
From measured data, generally, the average wind speed in the study area registered a low values below $2 \mathrm{~ms}^{-1}$ (between 0.4 to $1.7 \mathrm{~ms}^{-1}$ ). The highest wind speed $\left(1.7 \mathrm{~ms}^{-1}\right)$ was recorded at point 14 which located nearby man-made lakes. The lowest wind speed distributions $\left(0.4 \mathrm{~ms}^{-1}\right)$ were recorded at points 8 and 11 which located nearby vegetated area. Hence, it indicates that the areas located nearby water body (lakes) demonstrate highest velocity rather than other locations. This is probably due to the characteristic of the lakes where it is quite open area and not obstructed by the density of buildings or vegetation. On the other hand, the areas comprise of woody vegetation and forest area demonstrates lowest wind velocity. This is due to the characteristic of the locations where the density of trees tends to obstruct the wind velocity.

\subsection{Urban thermal variation and relationship with morphological elements}

The isothermal map (Figure 4) showing the urban thermal variation in Putrajaya was produced using ArcGIS 10 by using spatial interpolation method where the data were analysed through IDW (Inverse Distance Weighted) analysis.

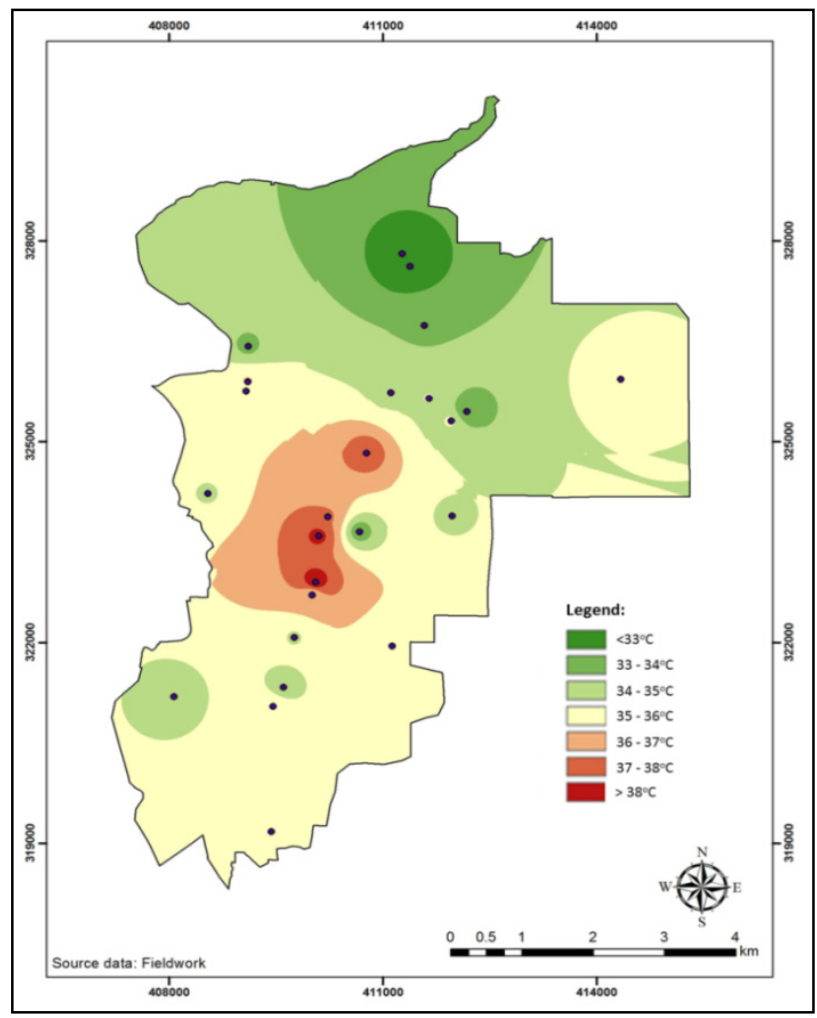

Figure 4: $\quad$ The isothermal map of temperature distribution in the study area. 
From the isotherm map, it can be seen that the area of green coverage (green colours) demonstrated lower temperature rather than the built-up coverage (red colours). This is possibly because, the built-up or urban centre (Precinct 2, 3, 4, 9 and 15) comprises of many land use types and typified by impervious surfaces, large building blocks and less vegetation compared to green areas (typified by forest, local parks and wetlands) that located at the northern part (Precinct 11, 12 and 13) of Putrajaya. Therefore, the typified morphological elements in urban core area have resulted to the uprising temperature in the urban centre.

Table 2 indicates the morphological aspects in the study area that gives influence to the variation of temperature in the study area.

Table 2: $\quad$ Morphological aspect that gives significant influence to the urban thermal variation in the study area.

\begin{tabular}{|l|l|c|}
\hline $\begin{array}{l}\text { Morphological } \\
\text { aspect }\end{array}$ & Urban characteristics & $\begin{array}{l}\text { Variation of } \\
\text { temperature } \\
\left({ }^{\circ} \mathrm{C}\right)\end{array}$ \\
\hline Vegetation & $\begin{array}{l}\text { Dense vegetation, shading cast by tree } \\
\text { canopies }\end{array}$ & $<33$ \\
\hline Water body & Presence of dense vegetation & $33-34$ \\
\cline { 2 - 3 } & Surrounded by sparse vegetation & $34-35$ \\
\hline \multirow{2}{*}{$\begin{array}{l}\text { Urban } \\
\text { complex }\end{array}$} & $\begin{array}{l}\text { Streetscapes, street trees/planting, } \\
\text { local park }\end{array}$ & $34-35$ \\
\cline { 2 - 3 } & $\begin{array}{l}\text { Paved/grassy surfaces, shading cast } \\
\text { by buildings or trees, presence of little } \\
\text { vegetation }\end{array}$ & $35-36$ \\
\cline { 2 - 3 } & $\begin{array}{l}\text { Open spaces, partially shading by } \\
\text { buildings/ trees, paved surfaces }\end{array}$ & $36-37$ \\
\cline { 2 - 3 } & $\begin{array}{l}\text { Open spaces, no shading, bare soil, } \\
\text { absence of vegetation }\end{array}$ & $37-38$ \\
\cline { 2 - 3 } & $\begin{array}{l}\text { Open spaces, no shading, paved } \\
\text { surfaces, absence of vegetation }\end{array}$ & $>38$ \\
\hline
\end{tabular}

The research revealed that the cooling effect of green areas can be observed at a macro scale. This is because; the temperature measurement near to high density of green areas (the forestland, urban parks etc.) consistently experienced low temperature rather than areas with less vegetation or at urban centre. This finding agree with the study by Wong and $\mathrm{Yu}$ [18] that indicated the maximum difference of $4.01^{\circ} \mathrm{C}$ between well planted areas with urban core area in Singapore.

Figure 5 illustrates the urban thermal variation within various urban landscapes morphology of Putrajaya. The figure depicts the relationship between morphological aspects on the uprising thermal condition where the morphology typified by bioclimatic components (vegetation and water body) demonstrated 
the lower thermal variation whilst the urban architectural complexes demonstrated higher thermal variation. This indicates that large proportion of green areas and utilisation of bioclimatic elements could improve the urban climate and helps to provide urban thermal comfort.

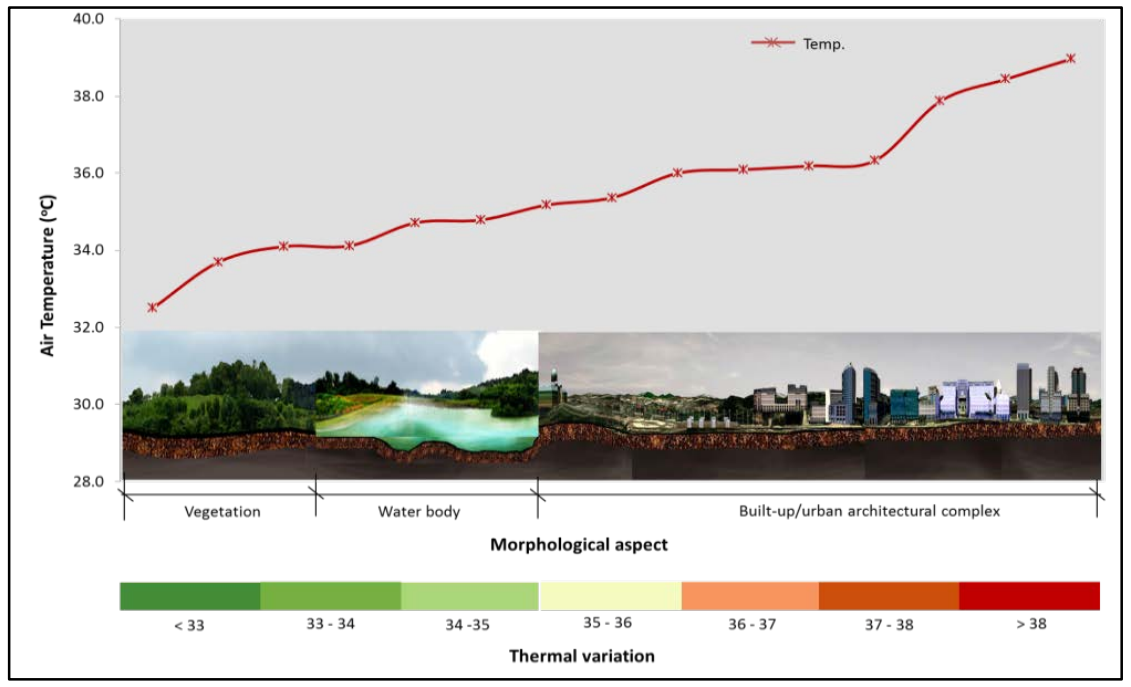

Figure 5: Schematic depiction of thermal variation and relationship with morphological aspect.

\section{$5 \quad$ Conclusion and recommendations}

This research founds that the microclimatic variation depending on the morphological factors of urban landscapes where the temperature, relative humidity and wind speed distributions was varied in different urban landscapes. This indicates that the urban landscape morphology influenced the variations and distribution of climatic parameters. It gives impact to the local climate of the study area. Based on the findings, there were significant relationship between urban landscape morphology and its climatic variations where it was indicated that the features and characteristics of urban landscape have great influence to the microclimatic condition in the study area.

This research also reaffirms that urban landscaping and greenery have many positive impacts in moderating urban climate. It can be shown that the areas mostly covered with bioclimatic components such as vegetation and water elements are the low-temperature zone. This indicates that the bioclimatic components could be beneficial as daytime cooling agent in the built environment and have significant impact to the modification of urban temperature.

This research also suggests that the practitioners in landscape architectural profession should have basic understanding on the relationship between native 
vegetation and the local climate, and adaptability to the physical environment in hot-humid climate. This is especially true for humid tropics where the abundance of natural vegetation can be utilised to provide thermal benefits. The comprehensive understanding on the potential of natural vegetation as urban thermal modifier could help the practitioners in designing a climate-responsive urban landscape for future development.

\section{Acknowledgements}

The authors would like to express great appreciation to Universiti Teknologi MARA (UiTM) and Putrajaya Corporation (PPj) for their assistance given during the progress of the study. This research paper is supported by a grant of Research Intensive Faculty (RIF) provided by Research Management Institute (RMI), Universiti Teknologi MARA (600-RMI/DANA/5/3/RIF (111/2012).

\section{References}

[1] Gartland, L., (2008). Heat Islands: Understanding and mitigating heat in urban areas. Earthscan, London, Sterling VA, (Chapter 2).

[2] Sharifah Khalizah, S.O.T., Nik Hanita, N.M., Sharifah Mastura, S.A., (1922 March 2013). The Influence of Urban Landscape Morphology on the Temperature Distribution of Hot-Humid Urban Centre. (Proceeding) ASEAN Conference on Environment-Behaviour Studies, Hanoi, 2013.

[3] Shaharuddin, A. (2012). Mikroiklim Bandar: Perkembangan dan impak pulau haba bandar di Malaysia (In Malay). Penerbit Universiti Kebangsaan Malaysia.

[4] Emmanuel, R., Johansson, E., (2006). Influence of urban morphology and sea breeze on hot humid microclimate: the case of Colombo, Sri Lanka. Climate Research, 30, pp. 189-200.

[5] Givoni, B., (1998). Climate consideration in building and urban design. John Wiley \& Son. Inc.

[6] Oke, T.R., (1987). Boundary Layer Climate. Second Edition. Methuen: London and New York.

[7] Sharifah Khalizah, S.O.T., Nik Hanita, N.M., Sabrina, I. Modification of urban temperature in hot-humid climate through landscape design approach: A review. Procedia-Social and Behavioural Sciences, 68, pp. 439-450.

[8] Yeang K., (2006). ECODESIGN: A Manual for Ecological Design, John Wiley \& Sons, Ltd.

[9] Olygay V., (1973). Design with Climate: Bioclimatic Approach to Architectural Regionalism. Princeton University Press. pp. 30-31, 74, 173.

[10] Fintikakis, N., Gaitani, N., Santamouris, M., Assimakopoulus, M., Assimakopoulus D.N., Fintikaki, M., Albanis. G., Papadimitriou, K., Chryssochoides, E., Katopodi, K., Doumas, P., (2011). Bioclimatic design of open public spaces in the historic centre of Tirana, Albania. Journal of Sustainable Cities and Society 1, pp. 54-62. 
[11] Corbella, O.D., Magalhães, M.A.A.A., (2008). Conceptual differences between the bioclimatic urbanism for Europe and for tropical humid climate. Journal of Renewable Energy 33, pp. 1019-1023.

[12] Emmanuel, M.R. (2005). An urban approach to climate sensitive design Strategies for the tropics. Spon Press Taylor \& Francis Group.

[13] Sun, R., Chen, A., Chen, L., Lu, Y., (2012). Cooling effects of wetlands in an urban region: The case of Beijing. Ecological Indicators 20, pp. 57-64.

[14] Sun, R., Chen, L., (2012). How can urban water bodies be designed for climate adaptation? Journal of Landscape and Urban Planning 105, pp. 27-33.

[15] Shahidan, M.F., Shariff, M.K.M., Jones, P., Salleh, E., Abdullah A.M., (2010). A comparison of Mesua ferrea L. and Hura crepitans L. for shade creation and radiation modification in improving thermal comfort. Journal of Landscape and Urban Planning, 97, pp. 168-181.

[16] Hidayat, I.W., 2010, The Ecological Role of Trees and their Interactions in Forming the Microclimate Amenity of Environment, Jurnal Bumi Lestari, Volume 10 No. 2, Augustus 2010, hlm. pp. 182-190.

[17] Draft Structure Plan: Putrajaya 2025, 2011.

[18] Wong, N.H., Yu, C. (2005). Study of green areas and urban heat island in a tropical city. Habitat International, 29, pp. 547-558. 